\title{
PENGEMBANGAN INSTRUMEN KEMAMPUAN BERPIKIR KRITIS DAN HASIL BELAJAR IPS PADA SISWA KELAS V SD
}

\author{
K.T. Marselina ${ }^{1}$, I.W.Lasmawan ${ }^{2}$, N. Dantes ${ }^{3}$ \\ ${ }^{123}$ Program Studi Pendidikan Dasar \\ Universitas Pendidikan Ganesha \\ Singaraja, Indonesia \\ e-mail: mingtria10@yahoo.com ${ }^{1}$, wayan.lasmawan@undiksha.ac.id ${ }^{2}$, \\ dantes@undiksha.ac.id ${ }^{3}$
}

\begin{abstract}
Abstrak
Penelitian ini bertujuan untuk mengetahui: 1) Untuk mengetahui dan mendeskripsikan tingkat validitas isi instrumen kemampuan berpikir kritis dan hasil belajar IPS pada siswa kelas V SDN 3 Kawan Bangli; 2) Untuk mengetahui dan mendeskripsikan tingkat validitas emperik instrument kemampuan berpikir kritis dan hasil belajar IPS pada siswa kelas V SDN 3 Kawan Bangli; 3) Untuk mengetahui dan mendeskripsikan tingkat reliabilitas instrument pengembangan kemampuan berpikir kritis dan hasil belajar IPS pada siswa kelas V SDN 3 Kawan Bangli. Penelitian ini tergolong penelitian pengembangan, pengembangan yang dilakukan adalah pengembangan instrument kemampuan berpikir kritis dan hasil belajar IPS. Tahap pengembangan yang digunakan adalah tahap pengembangan instrument tes oleh Djamari Mardapi. Data dianalisis dengan menggunakan Content Validity Ratio (CVR) untuk validitas expert yang diuji expert sebanyak lima orang orang dosen untuk instrument kemampuan berpikir dan dua dosen tiga guru untuk instrument hasil belajar IPS, Korelasi Poin Biserial untuk validitas empiric, dan uji statistic KR20 untuk reliabilitas. Hasil penelitian ini menunjukan bahwa: 1) instrument kemampuan berpikir kritis, berdasarkan uji expert dikatagorikan valid dengan nilai CVR 1 dan 0,6 dan instrument hasil belajar IPS, berdasarkan uji expert dikatagorikan valid dengan nilai CVR 1;2) validitas empiric instrument kemampuan berpikir kritis dinyatakan valid sesuai dengan analisis korelasi poin biserial yang ditunjukan dengan setiap butir memperoleh $r_{\text {hitung }} \geq r_{\text {tabel }}(0,3008$ untuk signifikansi $5 \%)$ dan hasil validitas empiric instrument hasil belajar IPS juga dinyatakan valid sesuai dengan analisis korelasi poin biserial yang ditunjukan dengan setiap butir memperoleh $r_{\text {hitung }} \geq r_{\text {tabel }}(0,3008$ untuk signifikansi $5 \%)$; 3 ) Hasil uji reliabilitas pada instrument kemampuan berpikir kritis dan hasil belajar IPS diperoleh bahwa semua indikator memiliki nilai Corrected Item-Total Correlation lebih besar dari nilai R-tabel $(0,3008)$ sehingga dapat dinyatakan bahwa soal tersebut reliabel.
\end{abstract}

Kata kunci: Hasil Belajar IPS; Kemampuan Berpikir Kritis; Pengembangan Instrumen

\begin{abstract}
The aim of this study was to find 1) to know and describe the level of content validity of critical thinking skill instrument and outcomes learning of social study at Fifth grade student of SDN 3 Kawan Bangli; 2)to know and describe the level of empiric validity of critical thinking skill instrument and outcomes learning of social study at Fifth grade student of SDN 3 Kawan Bangli; 3) to know ang describe the level of content reliability critical thinking skill instrument and outcomes learning of social study at Fifth grade student of SDN 3 Kawan Bangli. This research is classified as development research, the development carried out is the development of critical thinking ability instruments and social studies learning outcomes. The development stage used is the test instrument development stage by Djamari Mardapi. Analysis of the data used content validity ratio (CVR) for expert validity test used five lecturers for thinking skill instrument and two lecturers and three teachers for outcomes learning of social study instrument, correlation of biserial point for empiric validity, statistic test KR20 for reliability. The result of the study showed that: 1) critical thinking skill instrument based on expert test catagirized valid with CVR score 1 and 0,6 and outcomes learning of social study instrument based on expert test categorized valid
\end{abstract}


with CVR score 1; 2) validity of critical thinking skill instrument declared valid suitable with corelationt of biserial point analysis which showed in every point rcount $\geq$ rtable $(0,3008$ for significance 5\%) and validity of empiric instrument outcomes learning of social study was declared valid suitable with corelationt of biserial point analysis which showed in every point rcount $\geq$ rtable $(0,3008$ for significance $5 \%)$; 3) The results of the reliability test on the instrument of critical thinking ability and social studies learning outcomes obtained that all indicators have a Corrected Item-Total Correlation value greater than the R-table value (0.3008) so that it can be stated that the question is reliable

Keywords: Outcomes Of Social Study; Critical Thinking Skill; The Development Of Instrument

\section{PENDAHULUAN}

Di era sekarang ini, teknologi komunikasi dan infomasi berpengaruh besar bagi perubahan pola hidup setiap orang. Di abad yang ke 21 perkembangan teknologi tidak bisa dipisahkan dari setiap aspek kehidupan manusia, termasuk dunia pendidikan. Setiap siswa dan guru wajib untuk memiliki kemampuan menguasai teknologi dan komunikasi untuk memudahkan mereka dalam belajar.

Pendidikan yang memiliki kualitas paling baik akan menjadi ikon dari sebuah bangsa yang memiliki kemajuan atau yang disebut dengan negara maju. Pendidikan memiliki peran penting untuk membangun SDM yang bisa memiliki kemampuan bersaing untuk mengembangkan teknologi saat ini dan ilmu pengetahuan. Pendidikan seharusnya terus dikembangkan kuantitas dan kualitasnya secara optimal sesuai tujuan pendidikan (Juandi, 2019). Dengan pengelolaan pembelajaran yang optimal bisa meningkatkan kemampuan pengetahuan siswa yang baik. Kemampuan belajar siswa yang penting untuk ditingkatkan oleh lembaga sekolah ialah kemampuan yang relevan dengan relaitas yang sedang dan akan dihadapi oleh siswa setelah selesai dari dari kegiatan belajar di sekolah agar siswa bisa menerapkannya di kehidupan sehari-hari dan bermanfaat bagi masyarakat serta bangsa dan negara.

Dalam Pemendikbud No $81 \mathrm{~A}$ (2013) dinyatakan bahwa proses pembelajaran dalam kurikulum 2013 tersusun dari lima kegiatan pembelajaran, antara lain aosiasi, pengeumpulan informasi, menanyakan, pengamatan dan komunikasi. Pengamatan lebih berkaitan pada proses belajar yang memfokuskan kebermaknaan.

Selanjutnya kegiatan menanyakan ialah pengajuann pertanyaan terkait pemahaman yang masih kurang atas apa yang digali atau untuk memperoleh informasi yang baru dan lebih jelas. Untuk menindaklanjuti kegiatan bertanya, siswa ditugaskan untuk melakukan aktivitas pengumpulan informasi melalui cara-cara tertentu. Dengan sebab itu, siswa bisa mendapatkan informasi yang saling berkaitan dan memperoleh pola-pola keberkaitan informasi tersebut (Nurjan, 2016).

Pembelajaran IPS tidak sematamata merupakan pelajaran hafalan yang diingat siswa dalam kurun waktu tertentu kemudian dilupakan begitu saja. IPS berkaitan dengan fakta, realitas, generalisasi, konsep dan peristiwa yang saling terkait dengan informasi di masyarakat. Dalam BSNP (2006: 575) mata pelajaran IPS memiliki tujuan untuk membantu siswa mempunyai berbagai potensi seperti : 1) Mengetahui pengetahuan terkait perilaku hidup masyarakat dan sekitarnya; 2) Mempunyai keterampilan dasar dalam mengembangkan pola pikirnya secara kritis, logis, keingintahuan, bisa menyelesaikan persoalan dan keterampilan lainnya dalam keberlangsungan hidup di masyarakat; 3) Mempunyai rasa sadar dan motivasi atas nilai-nilai kemanusiaan dan sosial; 4) Mempunyai keterampilan dalam melakukan kerjasama, kompetisi dan komunikasi di masyarakat. 
Pembelajaran IPS di lembaga pendidikan focus dalam penekanan terhadap berbagai aspek seperti keterampilan, sikap, pengetahuan dan persoalan-persoalan lainnya yang dihadapi siswa di kehidupannya. Seorang pendidik hendaknya bisa memberikan motivasi bagi siswa untuk lebih kreatif, inovatif, aktif dan bisa menyelesaikan permasalahn secara sistematis (Thamaria, 2003). Selain guru, aspek lain yang bisa mempengaruhi hasil belajar IPS siswa ialah aspek dari diri peserta didik tersebut yakni memiliki pola pikir yang kritis.

Sebuah sistem belajar mengajar
yang cenderung focus pada
pengembanan pola piker kritis siswa
dapat memudahkan siswa untuk
menyelesaikan suatu persoalan dan
bisa menggali informasu yang bermanfaat kemudian menyalurkannya untuk hal-hal yang memberikan dampak positif bagi kemajuan pendidikan. Apabila siswa terus mengembangkan kemampuan pola pikir kritisnya akan mempermudahnya dalam memahami pelajaran. Kemampuan berpikir kritis juga bisa dikembangkan dengan latihanlatihan sehingga bisa meningkatkan keterampilan berpikir kritis, kreatif dan imajinatif dalam proses pembelajaran (Hidayati \& Listyani, 2013). Kemampuan dalam penelitian ini menyangkut pada kemampuan intelektual yakni kemampuan yang dimiliki siswa untuk memberikan pendapat dalam menyelesaikan persoalan berkaitan dengan tema yang dibahas dan dapat memecahkan berbagai masalah dalam pembelajaran sehingga berdampak pada keterampilan pola pikir kritis yang tinggi dan pencapaian belajar siswa menjadi baik.

Terkait hasil wawancara yang dilakukan bersama wali kelas V SDN 3 Kawan pada Senin, 22 Februari didapatkan informasi tentang masalah yang dialami oleh siswa pada pemberian hasil belajar siswa. Peneliti melakukan telaah instrumen penilaian yang digunakan. Instrumen yang sudah ada sebelumnya dan tanpa adanya pengembangan dari pendidik menjadi kurang baik kualitasnya. $\mathrm{Hal}$ ini disebabkan kemampuan berpikir Taksonomi Bloom Revisi terbatas pada C1 (mengetahui) dan C2 (memahami). Instrumen tersebut belum mampu memenuhi keterampilan abad 21 agar peserta didik bisa terbiasa dalam mengkaji instrument dengan pola pikir yang tidak kritis.

Kekurangan pembelajaran dalam pendidikan IPS ialah kegiatan belajar yang terbatas bagi siswa dan peranan pengajar yang dominan di dalam proses belajar mengajar. Pemberian butir soal yang LOTS. Hal ini mengakibatkan lemahnya proses dan menjadikan pencapaian belajar menjadi rendah. Hal ini menjadikan pelaksanaan sistem belajar mengajar menjadikan siswa merasa lelah dan bosan, pengetahuan yang didapatkan hanya berupa informasi dan fakta yang sifatnya abstrak. Siswa hanya focus pada metode hafalan, sehingga menyebabkan siswa kurang di dalam bertindak dan berpikir. Hal ini menjadikan pengembangan kemampuan siswa sebatas pengembangan kognitif tingkat dasar saja dan belum sampai pada pengembangan pola pikir yang kritis. Apabila metode yang diterapkan hanya sebatas hafalan menjadikan siswa memiliki pengetahuan yang sedikit dan menjadikannya bergantung sebatas apa yang disampaikan oleh guru. Siswa tidak memiliki kemampuan untuk belajar secara mandiri dan sulit untuk menyelesaikan permasalahan dengan sendiri. Sehingga melalui pembelajaran semacam ini menjadikan siswa tidak memiliki kemampuan untuk bertanya atas apa yang belum dipahami. Hal ini tentunya akan menimbulkan kesenjangan antara tujuan dan harapan yang hendak dicapai dalam mata pelajaran IPS dengan kenyataannya yang terjadi di lapangan (Wijaya, 2020).

Instrumen berpikir kritis dan hasil belajar IPS yang dipakai oleh pengajar sebatas soal latihan yang telah ada di 
modul. Pengajar cenderung fokus dalam memberikan pemahaman terhadap siswa untuk menguasai konsep IPS sehingga tes berpikir kritis dan hasil belajar IPS yang dikaji belum ada dan perlu diadakan serta dirancang dalam pengembangan keterampilan berpikir kritis dan hasil belajar IPS siswa sehingga instrumen tersebut sesuai dengan tuntutan belajar abad 21, pada bagian 4C yakni critical thinking.

Tuntutan era sekarang ini menjadikan guru mengubah pola pikirnya dalam memahami pencapaian belajar sesuai dengan tujuan pendidikan abad 21. Suapa peserta didik bisa mempunyai kemampuan yang baik maka pengajar hendaknya mempunyai instrument yang sesuai keperluan keterampilan pola pikir yang kritis dan hasil belajar IPS siswa (Mahanal \& Zubaidah, 2017). Di antara penyebab kemunculan keterampilan pola pikir kritis yang rendah pada peserta didik pada pelajaran IPS ialan kualitas instrument yang kurang mumpuni. Oleh sebab itu perlu adanya pengembangan instrumen berpikir dan untuk hasil belajar IPS siswa.

Terkait dengan persoalan tersebut maka peneliti memiliki upaya untuk mengurangi hal itu melalui penelitian yang berjudul "Pengembangan Instrumen Kemampuan Berpikir Kritis Dan Hasil Belajar Pada Siswa Kelas V SDN 3 Kawan Bangli Tahun Ajaran 2020/2021."

\section{METODE}

Penelitian "Pengembangan Instrumen Kemampuan Berpikir Kritis Dan Hasil Belajar IPS Pada Siswa Kelas $\checkmark$ SDN 3 Kawan Bangli Tahun Ajaran 2020/2021" ini menggunakan rancangan penelitian Research and Development (R\&D). Penelitian ini menggunakan model penelitian dan pengembangan (educatioSnal research and development). (Kurniati et al., 2015)menjelaskan bahwa penelitian dan pengembangan adalah suatu proses/langkah mengembangkan suatu produk dan menyempurnakan suatu produk dan dapat dipertanggungjawabkan. Sejalan dengan itu, Sugiyono (2012) menyebutkan bahwa penelitian dan pengembangan dapat digunakan untuk menghasilkan sebuah produk dan dapat menguji keefektifan produk yag telah dikembangkan. Pengembangan instrumen kemampuan berpikir kritis dan hasil belajar IPS menggunakan model pengembangan Djemari Mardapi.

Tahapan model pengembangan Djemari Mardapi dibatasi dan disesuaikan dengan kebutuhan peneliti. Dari kesembilan langkah model pengembangan tersebut, tidak semua langkah digunakan dalam penelitian ini. Penerapan tahapan tersebut pada penelitian ini hanya melalui tahap menyusun spesifikasi tes, menulis soal tes, menelaah soal tes, melakukan uji coba tes, menganalisis butir soal tes, memperbaiki tes dan menafsirkan hasil tes. Langkah pengembangan instrumen menurut Djemari Mardapi yang tidak digunakan dalam penelitian ini adalah merakit tes dan melaksanakan tes. Merakit tes tidak digunakan karena langkah tersebut dilakukan pada saat memperbaiki tes. Sedangkan tahap melaksanakan tes tidak digunakan karena langkah tersebut sama dengan tahap uji coba. Dengan asumsi bahwa hasil telaah yang dilakukan para ahli mampu menjamin kualitas instrumen yang dibuat, maka uji coba yang dilakukan dalam penelitian ini cukup sekali yaitu pada langkah kelima.

Adapun langkah pengembangan instrument yang digunakan pada penelitian ini adalah menyusun spesifikasi tes, menulis soal tes, menelaah soal tes, melakukan uji coba, menganalisi soal, memperbaiki tes, merakit tes, melaksanakan tes, menafsirkan hasil tes (Cooke et al., 2011).

1) Menyusun spesifikasi tes. Hal-hal yang dilakukan ketika menyusun spesifikasi tes adalah menentukan tujuan tes, menyusun kisi-kisi, memilih bentuk tes, dan tes sumatif. Hal ini dilakukan agar mempermudah 
dalam menulis soal dan siapa saja yang menulis soal akan menghasilkan tingkat kesulitan yang relatif sama.

2) Menulis soal tes. Penulisan soal merupakan penjabaran dari indikator menjadi pertanyaan-pertanyaan yang karakteristiknya sesuai dengan perincian pada kisi-kisi yang telah dibuat.

3) Menelaah soal tes. Hal ini dilakukan untuk meminimalisir kesalahan atau kekurangan.

4) Melakukan uji coba tes. Uji coba tes dilakukan sebagai sarana memperoleh data empiris tentang tingkat kebaikan soal yang telah disusun.

5) Menganalisis butir-butir soal tes. Dengan adanya analisis butirbutir soal tes dapat dikatahui tingkat kesulitan butir soal, daya pembeda, dan efektivitas pengecoh.

6) Memperbaiki tes. Langkah ini biasanya dilakukan tes butir soal, yaitu memperbaiki masing-masing butir soal yang ternyata masih belum baik.

7) Menafsirkan hasil tes. Hasil tes menghasilkan data kuantitatis yang berupa skor. Skor ini kemudian ditafsirkan sehingga menjadi nilai, yaitu rendah, menengah atau tinggi. Tinggi rendahnya nilai selalu dikaitkan dengan acuan penilaian. Terdapat dua acuan penilaian yang sering digunakan dalam dunia psikologi dan pendidikan, yaitu acuan norma dan acuan kriteria.

Subyek penelitian yang digunakan dalam penelitian ini yaitu subyek untuk validitas dan subyek untuk tes. Subyek untuk memvalidasi tes yaitu dua orang validator. Validator merupakan ahli dalam bidangnya yaitu ahli dalam bidang pendidikan dan ahli dalam bidang asesmen. Subyek yang digunakan untuk tes adalah siswa kelas V SDN 3 Kawan Bangli Tahun Ajaran 2020/2021.

Variabel penelitian ini adalah kualitas Alat Ukur Kemampuan Berpikir Kritis dan Hasil Belajar IPS Siswa.
Indikator variabel kualitas pengembangan dalam penelitian ini meliputi alat ukur kemampuan berpikir kritis dan penilaian hasil belajar siswa.

Metode pengumpulan data adalah cara-cara yang dapat digunakan oleh peneliti untuk mengumpulkan data. Cara memperoleh data penelitian ini adalah menggunakan tes dan angket. Tes adalah alat atau prosedur yang digunakan untuk mengukur sesuatu dalam suasana dengan cara-cara dan aturan-aturan yang sudah ditentukan. Tes adalah serentetan pertanyaan atau latihan serta alat lain yang digunakan untuk mengukur keterampilan, pengetahuan, intelegensi, kemampuan atau bakat yang dimiliki individu atau kelompok (Widoyoko, 2020). Tes berisi permasalahan untuk dipecahkan oleh peserta didik. Tes yang akan diberikan merupakan soal-soal IPS yang ada pada buku tema 9 kelas $\mathrm{V}$ yang sesuai dengan tingkat kognitif siswa kelas $\mathrm{V}$ SD. Soal tes yang diberikan pilihan ganda, yang mengacu pada indikator pembelajaran IPS. Angket sebagai alat penilaian digunakan untuk mengetahui pendapat, aspirasi, harapan, prestasi, keinginan, keyakinan, dan lain-lain sebagai hasil belajar peserta didik (Mastur, Sughirato, 2015). Angket atau kusioner adalah sejumlah pertanyaan tertulis yang digunakan untuk memperoleh informasi dari responden dalam arti laporan tentang pribadinya atau hal yang ia ketahui. Angket yang digunakan pada penelitian ini adalah lembar validasi tes. Validasi dilakukan berdasarkan validasi isi dan empiris serta bahasa dengan meminta pertimbangan dan penilaian dari dua validator yaitu ahli pendidikan dan ahli asesmen.

Data yang diperoleh dalam penelitian ini dianalisis sesuai dengan jenis dan kegunaannya dalam penelitian. Uji validitas isi kemampuan berpikir kritis dan hasil belajar IPS pada siswa kelas V SDN 3 Kawan Bangli ditempuh cara dengan menyusun tes berdasarkan kisi-kisi. Berdasarkan grand teori maka disusunlah kisi-kisi 
instrumen yang diimplementasikan menjadi butir-butir instrumen. Pada penelitian ini content validity dengan expert menggunakan formula Lawshe CVR (content validity ratio) yang melibatkan lima pakar ahli yaitu dosen untuk instrument kemampuan berpikit kritis, dua pakar ahli yaitu dosen tiga praktisi yaitu guru untuk instrument hasil belajar IPS. CVR (content validity ratio) merupakan teknik yang dikembangkan oleh Lawshe (1975) untuk mengukur kesepakatan di antara penilai tentang pentingnya item tertentu (Mahanal \& Zubaidah, 2017). Formula CVR yaitu sebagai berikut.

$$
C V R=\frac{n_{e}-\frac{N}{2}}{\frac{N}{2}}
$$

(Hendryadi, 2014)

Keterangan:

$$
\begin{array}{ll}
\text { CVR } & \text { Rasio Validitas isi } \\
\mathrm{n}_{\mathrm{e}}:{ } & \text { Jumlah panelis yang } \\
& \begin{array}{l}
\text { memberikan penilaian } 3 \\
\text { (relevan) }
\end{array}
\end{array}
$$

$\mathrm{N}$ : Banyaknya panelis

Kriteria valid tidaknya isi butir rubrik menggunakan acuan nilai minimum CVR berdasarkan jumlah panelis. Isi butir dinyatakan valid apabila memiliki CVR $\geq 0,60$.

Validitas empiris merupakan suatu ukuran yang menunjukkan tingkattingkat kesahihan atau kecermatan suatu alat ukur atau instrumen dalam melakukan fungsi ukurnya berdasarkan fakta empiris atau pengalamannya. Instrumen yang valid mempunyai validitas tinggi, artinya instrumen tersebut dapat mengukur apa yang hendak diukur. Uji Validitas untuk pilihan ganda digunakan korelasi point biserial karena skor 1 dan 0 saja. Adapun Uji Validitas butir pilihan ganda menggunakan korelasi point biserial sebagai berikut:

$$
\mathrm{r}_{\mathrm{pbi}}=\frac{\mathrm{M}_{p}-\mathrm{M}_{t}}{\mathrm{SD}_{t}} \sqrt{\frac{\mathrm{p}}{q}}
$$

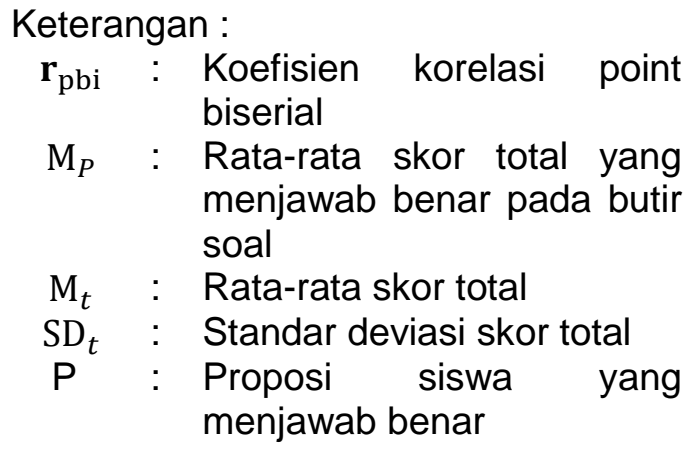

$\left(\mathrm{P} \frac{\text { banyaknya siswa yang menjawab benar }}{\text { jumlah seluruh siswa }}\right)$

q : proposi siswa yang menjawab $\operatorname{salah}(q=1-p)$

Setelah dihitung $\mathbf{r}_{\mathrm{pbi}}$ lalu dibandingkan dengan $r_{\text {tabel }}$ dengan taraf signifikan 5\% jika $r_{p b i}>r_{\text {tabel }}$ maka dikatakan soal tersebut valid.

Uji Reliabilitas Empirik engujian ini dimaksudkan untuk mengetahui sejauh mana alat ukur mepunyai konsistensi relatif tetap jika dilakukan pengukuran ulang terhadap subjek yang sama. Perhitungan koefisien reliabilitas instrumen dilakukan setelah butir yang tidak valid didrop atau tidak digunakan dalam perhitungan ini. Pada penelitian ini, uji reliabilitas angket tipe kepribadian menggunakan rumus KR-20 karena skor angket berupa data dikotomi (1 dan 0). Rumus KR-20 adalah sebagai berikut:.

$$
r_{11}=\left(\frac{n}{n-1}\right)\left(\frac{s^{2}-\sum p q}{s^{2}}\right)
$$

Keterangan

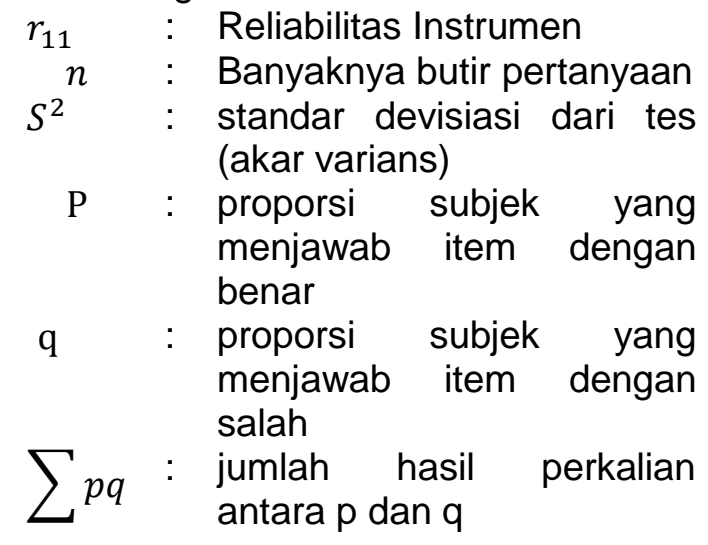


Kemudian hasil $r_{11}$ yang didapat dari perhitungan dibandingkan dengan harga $r_{\text {tabel }}$ dengan taraf signifikansi 5\% dan sesuai dengan jumlah butir soal. Jika $r_{11}>r_{\text {tabel }}$ maka dapat dinyatakan bahwa soal tersebut reliabel.

Tingkat kesukaran soal adalah peluang untuk menjawab benar suatu soal pada suatu tingkat kemampuan atau bisa dikatakan untuk mengetahui sebuah soal itu tergolong mudah atau sukar. Bilangan yang menunjukkan sukar dan mudahnya suatu soal disebut indeks kesukaran (difficulty indeks). Besarnya indeks kesukaran antara 0,00 - 1,00. Indeks kesukaran ini menunjukan taraf kesukaran soal, sehingga soal dengan indeks 0,00 menunjukkan bahwa soal itu terlalu sukar, sebaliknya indeks 1,0 menunjukkan bahwa soalnya terlalu mudah. Dalam evaluasi, indeks kesukaran ini diberi simbol $P$, singkatan dari "proporsa" (Alghafri \& Ismail, 2014)

\section{HASIL DAN PEMBAHASAN}

Penelitian ini merupakan
penelitian pengembangan yang
bertujuan untuk menghasilkan suatu produk dan dapat menguji keefektifan produk yag telah dikembangkan. Produk yang dihasilkan adalah Instrumen Kemampuan Berpikir Kritis Dan Hasil Belajar IPS Pada Siswa Kelas V, pengembangan ini menggunakan rancangan penelitian Research and Development (R\&D). Pengembangan instrumen kemampuan berpikir kritis dan hasil belajar IPS menggunakan model pengembangan Djemari Mardapi. Tahapan model pengembangan Djemari Mardapi dibatasi dan disesuaikan dengan kebutuhan peneliti.

Dari kesembilan langkah model pengembangan tersebut, tidak semua langkah digunakan dalam penelitian ini. Penerapan tahapan tersebut pada penelitian ini hanya melalui tahap menyusun spesifikasi tes, menulis soal tes, menelaah soal tes, melakukan uji coba tes, menganalisis butir soal tes, memperbaiki tes dan menafsirkan hasil tes. Langkah pengembangan instrumen menurut Djemari Mardapi yang tidak digunakan dalam penelitian ini adalah merakit tes dan melaksanakan tes. Merakit tes tidak digunakan karena langkah tersebut dilakukan pada saat memperbaiki tes. Sedangkan tahap melaksanakan tes tidak digunakan karena langkah tersebut sama dengan tahap uji coba. Dengan asumsi bahwa hasil telaah yang dilakukan para ahli mampu menjamin kualitas instrumen yang dibuat, maka uji coba yang dilakukan dalam penelitian ini cukup sekali yaitu pada langkah kelima.

Validitas instrument kemampuan berpikir kritis meliputi validitas isi yang didasari dari hasil validasi oleh pendapat ahli (expert judgment) dak praktisi Pendidikan untuk pembelajaran IPS kelas V SD pada tema 9. Tahapan validasi awal untuk instrument kemampuan berpikir kritis adalah validasi expert oleh 5 orang dosen dari jurusan Pendidikan dasar.

Hasil dari expert judgment selanjutnya dilakukan analisis untuk mendapatkan indeks rasio validitasnya dengan melakukan perhitungan Content validity Ratio (CVR). Rubrik penskoran untuk expert menggunakan skala 3, yaitu relevan (3), kurang relevan (2), dan tidak relevan (1). Hasil uji validitas instrument kemampuan berpikir kritis yang dikembangkan. Dari hasil uji validitas isi instrument kemampuan berpikir kritis terdapat sebanyak 30 butir soal pernyataan valid, dengan nilai CVR 1,000 untuk nomor butir soal $1,4,5,6$, $7,8,9,10,11,12,14,15,16,17,18$, $19,20,21,22,24,25,26,27,28,29$, 30 , dan nilai CVR 0,600 untuk nomor butir soal 2, 3, 13, 23, sedangkan untuk instrument hasil belajar IPS , terdapat sebanyak 30 butir soal pernyataan valid, dengan nilai CVR 1,000.

Setelah uji expert, dilakukan uji validitas empirik, uji validitas empirik digunakan untuk mengukur sah, atau valid tidaknya suatu kuesioner. Suatu kuesioner dikatakan valid jika pertanyaan pada kuesioner mampu untuk mengungkapkan sesuatu yang akan diukur oleh kuesioner tersebut. Uji 
signifikansi dilakukan dengan membandingkan nilai $r$ hitung dengan $r$ tabel untuk degree of freedom (df) $=\mathrm{n}-2$ $=41-2=39$, dalam hal ini $\mathrm{n}$ adalah jumlah sampel dan alpha $=0.05$ sehingga nilai $r$ tabel yaitu 0,3008 . Jika $r$ hitung lebih besar dari $r$ tabel dan nilai positif, maka butir atau pertanyaan atau indikator tersebut dinyatakan valid. Adapun hasil uji validitas menunjukkan bahwa semua indikator pada instrumen Kemampuan Berpikir Kritis sudah valid yang diukur dari nilai R-hitung lebih besar dari nilai R-tabel $(0,3008)$, dan untuk instrument hasil belajar IPS menunjukkan bahwa semua indikator pada instrumen Hasil Belajar sudah valid yang diukur dari nilai $R$-hitung lebih besar dari nilai $R$-tabel $(0,3008)$.

Uji realibilitas adalah instrumen yang bila digunakan beberapa kali untuk mengukur obyek yang sama, akan menghasilkan data yang sama. SPSS memberikan fasilitas untuk mengukur reliabilitas dengan uji statistik Cronbach Alpha (a). Suatu konstruk atau variabel dikatakan reliabel jika memberikan nilai Cronbach Alpha > 0,7 (Nunnally dalam Ghozali, 2012). uji reabilitas diperoleh bahwa variabel penelitian memiliki tingkat realibilitas yang baik dengan nilai Cronbach's Alpha > 0,70, sehingga dapat disimpulkan reabilitas yang baik. Maka, dapat dilanjutkan dengan pengolahan data melalui analisis regresi dengan memasukkan semua variabel penelitian.

Tingkat kesukaran soal adalah peluang untuk menjawab benar suatu soal pada suatu tingkat kemampuan atau bisa dikatakan untuk mengetahui sebuah soal itu tergolong mudah atau sukar. Bilangan yang menunjukkan sukar dan mudahnya suatu soal disebut indeks kesukaran (difficulty indeks). Besarnya indeks kesukaran antara 0,00 - 1,00. Indeks kesukaran ini menunjukan taraf kesukaran soal, sehingga soal dengan indeks 0,00 menunjukkan bahwa soal itu terlalu sukar, sebaliknya indeks 1,0 menunjukkan bahwa soalnya terlalu mudah. . hasil uji tingkat kesukaran pada instrumen kemampuan berpikir kritis diperoleh bahwa terdapat 12 pertanyaan yaitu pertanyaan $1,2,35,7$, $8,11,14,15,16,20$ dan 30 yang memiliki proporsi 0,71 - 1,00 yang artinya memiliki tingkat kesukaran yang mudah. Sedangkan sisanya 18 pertanyaan memiliki proporsi 0,41 0,70 yang artinya memiliki tingkat kesukaran yang sedang. Sedangkan hasil uji tingkat kesukaran pada instrumen hasil belajar diperoleh bahwa terdapat 24 pertanyaan yaitu pertanyaan $1,2,3,4,5,7,8,10,11,12,14,16,17$, $18,19,20,21,22,23,24,25,26,27,29$ dan 30 yang memiliki proporsi 0,71 1,00 yang artinya memiliki tingkat kesukaran yang mudah. Sedangkan sisanya 6 pertanyaan memiliki proporsi $0,41-0,70$ yang artinya memiliki tingkat kesukaran yang sedang.

Yang terakhir adalah uji daya beda, Menurut Anas Sudijono (2008) daya pembeda adalah kemampuan suatu butir item tes hasil belajar untuk dapat membedakan antara testee yang berkemampuan tinggi dengan testee yang berkemampuan rendah. hasil uji daya beda pada instrumen kemampuan berpikir kritis diperoleh bahwa terdapat 5 pertanyaan yaitu pertanyaan $4,9,10,1$ dan 22 yang memiliki nilai daya pembeda 0,70 - 1,00 yang artinya memiliki kategori daya pembeda yang sangat baik. Sedangkan sisanya 19 pertanyaan memiliki nilai daya pembeda $0,40-0,69$ yang artinya memiliki kategori daya pembeda yang baik dan terdapat 6 pertanyaan memiliki nilai daya pembeda $0,20-0,39$ yang artinya memiliki kategori daya pembeda yang cukup, sedangkan hasil uji daya beda pada instrumen hasil belajar diperoleh bahwa terdapat 5 pertanyaan yaitu pertanyaan $4,9,10,14$ dan 22 yang memiliki nilai daya pembeda $0,70-1,00$ yang artinya memiliki kategori daya pembeda yang sangat baik. Sedangkan sisanya 17 pertanyaan memiliki nilai daya pembeda $0,40-0,69$ yang artinya memiliki kategori daya pembeda yang baik dan terdapat 8 pertanyaan memiliki nilai daya pembeda $0,20-0,39$ yang 
artinya memiliki kategori daya pembeda yang cukup.

\section{PENUTUP}

Secara umum penelitian ini dapat disimpulkan bahwa tahapan model pengembangan Djemari Mardapi dibatasi dan disesuaikan dengan kebutuhan peneliti. Instrument yang dikembangkan pada penelitian ini yaitu kemampuan berpikir kritis dengan pengembangan menggunakan teknis tes berupa soal pilihan ganda, sedangkan instrument yang kedua dikembangkan yaitu hasil belajar IPS dengan pengembangan menggunakan teknis tes berupa soal pilihan ganda.

Penelitian pengembangan ini menghasilkan instrument kemampuan berpikir kritis berupa soal pilihan ganda sebanyak 30 butir soal. Selanjutnya dilakukan analisis uji validitas isi menggunakan CVR. Berdasarkan hasil perhitungan CVR semua soal dinyatakan valid. Selanjutnya analisis uji validitas empiric menggunakan korelasi point biserial dinyatakan semua indicator instrument kemampuan berpikir kritis dinyatakan valid yang diukur dari nilai $\mathrm{R}$-hitung lebih besar dari nilai R-tabel $(0,3008)$. Uji realiabilitas pada instrument kemampuan berpikir kritis diperoleh nilai 0,93 0,70 (rtabel), hasil uji tingkat kesukaran pada instrumen kemampuan berpikir kritis diperoleh bahwa terdapat 12 pertanyaan yang memiliki proporsi $0,71-1,00$ yang artinya memiliki tingkat kesukaran yang mudah. Sedangkan sisanya 18 pertanyaan memiliki proporsi 0,41 0,70 yang artinya memiliki tingkat kesukaran yang sedang, hasil uji daya beda pada instrumen kemampuan berpikir kritis diperoleh bahwa terdapat 5 pertanyaan yang memiliki nilai daya pembeda 0,70 - 1,00 yang artinya memiliki kategori daya pembeda yang sangat baik. Sedangkan sisanya 19 pertanyaan memiliki nilai daya pembeda 0,40 - 0,69 yang artinya memiliki kategori daya pembeda yang baik dan terdapat 6 pertanyaan memiliki nilai daya pembeda $0,20-0,39$ yang artinya memiliki kategori daya pembeda yang cukup.

Instrument kedua yaitu hasil belajar IPS berupa soal pilihan ganda sebanyak 30 butir soal. Selanjutnya dilakukan analisis uji validitas isi menggunakan CVR. Berdasarkan hasil perhitungan CVR semua soal dinyatakan valid. Selanjutnya analisis uji validitas empiric menggunakan korelasi point biserial dinyatakan semua indicator instrument hasil belajar IPS dinyatakan valid yang diukur dari nilai $R$ hitung lebih besar dari nilai R-tabel $(0,3008)$. Uji reliabilitas pada instrument hasil belajar IPS diperoleh nilai 0,92 > 0,70 (rtabel), sehingga dapat disimpulkan instrument hasil belajar IPS memiliki tingkat reabilitas yang baik. hasil uji tingkat kesukaran pada instrumen hasil belajar diperoleh bahwa terdapat 24 pertanyaan yang memiliki proporsi 0,71 - 1,00 yang artinya memiliki tingkat kesukaran yang mudah. Sedangkan sisanya 6 pertanyaan memiliki proporsi 0,41 - 0,70 yang artinya memiliki tingkat kesukaran yang sedang, hasil uji daya beda pada instrumen hasil belajar diperoleh bahwa terdapat 5 pertanyaan yang memiliki nilai daya pembeda $0,70-1,00$ yang artinya memiliki kategori daya pembeda yang sangat baik. Sedangkan sisanya 17 pertanyaan memiliki nilai daya pembeda 0,40 - 0,69 yang artinya memiliki kategori daya pembeda yang baik dan terdapat 8 pertanyaan memiliki nilai daya pembeda $0,20-0,39$ yang artinya memiliki kategori daya pembeda yang cukup.

\section{DAFTAR RUJUKAN}

Alghafri, A. S. R., \& Ismail, H. N. Bin. (2014). The Effects of Integrating Creative and Critical Thinking on Schools Students' Thinking. International Journal of Social Science and Humanity, 4(6), 518525.

https://doi.org/10.7763/ijssh.2014. v4.410

Cooke, A., Cavanagh, R., Hurst, C., \& 
Sparrow, L. (2011). Situational Effects Of Mathematics Anxiety In Pre-service Teacher Education. AARE 2011 Conference Proceedings, 1-14. http://aare.edu.au/11pap/papers_p df/aarefinal00501.pdf

Hidayati, K., \& Listyani, E. (2013). IMPROVING INSTRUMENTS OF STUDENTS' SELF-REGULATED LEARNING Kana Hidayati and Endang Listyani FMIPA UNY Mathematics Education Department. Jurnal Pendidikan Matematika Univertias Negeri Yogyakarta.

Juandi, A. (2019). Standar Penilaian Pendidikan.

https://doi.org/10.31227/osf.io/mun p2

Kurniati, I. D., Setiawan, R., Rohmani, A., Lahdji, A., Tajally, A., Ratnaningrum, K., Basuki, R., Reviewer, S., \& Wahab, Z. (2015). Buku Ajar.

Mahanal, S., \& Zubaidah, S. (2017). Model Pembelajaran RICOSRE yang Berpotensi Memberdayakan Keterampilan Berpikir Kreatif. Jurnal Pendidikan: Teori, Penelitian, Dan Pengembangan, 2(5), 676-685. http://journal.um.ac.id/index.php/jp tpp/article/view/9180

Mastur, Sughirato, S. (2015). Jurnal Bimbingan Konseling. Jurnal Bimbingan Konseling, 4(1), 23-29. https://doi.org/10.24036/XXXXXX $\mathrm{XXXX-X}$

Nurjan, S. (2016). Psikologi Belajar Edisi Revisi. BuatBuku.com

Thamaria, N. (2003). No 主観的健康感 を中心とした在宅高齢者における 健康関連指標に関する共分散構造 分析Title. Zitteliana, 18(1), 22-27.

Wijaya, H. (2020). Metode Penelitian Pendidikan Teologi. E-Modul, 09(January), https://www.researchgate.net/profil e/Hengki_Wijaya3/publication/338 230653_Metode_Penelitian_Pendi dikan_Teologi/links/5e16f3bb-9285 1c8364bd72d9/Metode-PenelitianPendidikan-Teologi.pdf 